Shades of White 

Pamela Perry

\section{Shades of White}

White Kids and Racial Identities in High School

Duke University Press Durham \& London 2002 
(C) 2002 Duke University Press

All rights reserved

Printed in the United States of

America on acid-free paper $\infty$

Designed by C. H. Westmoreland

Typeset in Bembo by

Keystone Typesetting, Inc.

Library of Congress Cataloging-

in-Publication Data appear

on the last printed page of this

book. 
To my parents, Marshall and Louise Perry 
